Article Type: Research Paper

\title{
The Impact of Marketing Expenditure on Firm Performance
}

\author{
Totok Haryanto $^{1 *}$ and Maharani Retnaningrum ${ }^{1}$
}

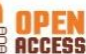

\section{AFFILIATION:}

${ }^{1}$ Departement of Management, Faculty of Economics and Business Universitas Muhammadiyah Purwokerto, Purwokerto, Indonesia.

\section{*CORRESPONDENCE:}

feb.ump.th@gmail.com

THIS ARTICLE IS AVALILABLE IN:

http://journal.umy.ac.id/index.php/mb

DOI: $10.18196 / \mathrm{mb} .11297$

\section{CITATION:}

Haryanto, T., \& Retnaningrum, M. (2020). The Impact of Marketing Expenditure on Firm Performance . Jurnal Manajemen Bisnis, 11(2), 188-201.

\section{ARTICLE HISTORY \\ Received:}

08 March 2020

\section{Reviewed:}

27 July 2020

12 August 2020

13 August 2020

Revised:

7 August 2020

Accepted:

21 August 2020

\begin{abstract}
This study aimed to examine whether marketing expenditure affected firm performance. Previous research has mentioned that there was an influence between marketing expenditure to profitability and firm value. However, some stakeholders and practitioners perceived that the budget for marketing expenditure has already overspent, which means it was assumed that marketing expenditure is very high cost and difficult to measure. In this research, the contribution of marketing expenditure to firm performance of the big four of the telecommunication companies in Indonesia (PT. Telkom, Tbk (including PT. Telkomsel), PT. Indosat Ooredoo, Tbk, PT. XL Axiata, Tbk, and PT. Smartfren Telecom, Tbk) would be analyzed. Firm performance was proxied as the profit margin on sales (PM on Sales), return on assets (ROA), return on investment (ROI), and return on equity (ROE). The methodology of the research used the quantitative model, and the analysis applied the simple regression. The results showed that the marketing expenditure had a significant effect on PM on Sales, $\mathrm{ROI}$, and ROE, partially. On the contrary, the marketing expenditure had no impact on the return on assets (ROA).

Keywords: Marketing Expenditure; PM on Sales; ROA; ROI; ROE; Firm Performance.
\end{abstract}

\section{Introduction}

There is a perception that marketing is considered an overspent aspect of a company, as it is difficult to measure its effectiveness and efficiency. An analysis is needed to measure marketing performance in accordance with the key performance indicator (KPI) set. The analysis should be objective and measurable so that it can be used to assess the level of profitability and productivity of the company. Hence, the enhancement of organizational performance requires some measurements to determine the impact of the level of organizational effectiveness upon business performance (Matari \& Mohammed, 2014).

Profitability analysis in the marketing context is an assessment conducted to examine the effects of various marketing strategies and tactics on the firm's expected profit contribution. Meanwhile, productivity analysis is an assessment of the consequences of sales or market share resulting from the implementation or realization of marketing strategies and tactics that have been set. The productivity analysis is concerned with estimating the correlation between the price or marketing cost incurred (e.g., advertising costs) with the volume and value of sales or market share that can be achieved within a specified period. 
In 2010, Indonesia's marketing expenditure reached 5.5 billion U.S. Dollars, and, in 2013, it reached 9.14 billion U.S. Dollars and was projected to increase every year. As with the results of Moorman and Rust (1999), marketing activities had a significant effect on sales. Besides, it is supported by another study (Kim \& Joo, 2013) concluded that the contribution of marketing expenditure could lift sales in all industries studied. Furthermore, research conducted by (Luo \& Jong., 2012) using stock return and risk as a dependent variable, found that marketing expenditure could also affect the firm value.

The result of research from (Sharma \& Husain, 2015) mentioned that there was a positive correlation among all the independent variables, i.e., the selling and marketing expenditure, dealers' commission, advertising expenses and salary, wages, employee benefits paid to the selling, and marketing staff of these companies. There was no significant impact of Selling \& Marketing expenditure on Gross Operating Profitability. However, other components of Selling and Marketing Expenditure, such as dealers' commission, advertising expenses, salary, wages, and employees benefit expenses, had a significant effect on the firms' profitability.

Figure 1 illustrates that spending on advertising includes digital (desktop/laptop, mobile, and other internet-connected devices), directories, magazines, newspapers, out-ofhome, radio, and TV. Advertising is part of marketing activities. The advertising spending changes annually with a different percentage. For example, the spending increased significantly from 2015 to 2016, almost doubled. Then, the advertising expenses had decreased in 2017 and stably for the following years until 2020 (first semester). The data indicates that the marketing activities still have a high portion in every business (manufacturing or services sectors). The main problem facing organizations is how to adjust the marketing budget in response to the business cycle (Peers, Heerde, \& Dekimped, 2017).

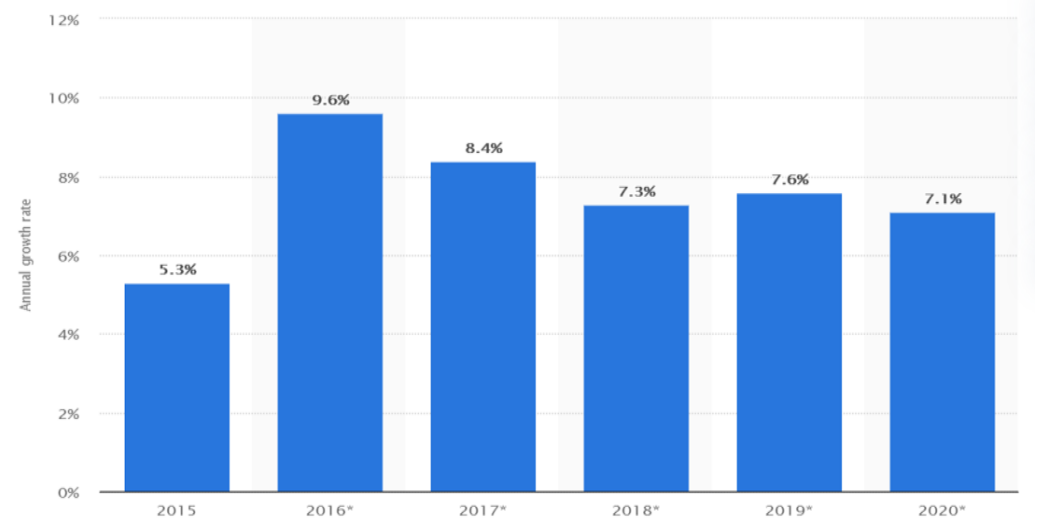

Figure 1 Change in advertising spending in Indonesia from 2015 to 2020 Source: eMarketer @statista.com (2020)

Figure 2 describes that Indonesia's total advertising market value was estimated to be around 2.57 billion U.S. Dollars in 2018. It was projected to increase to 5.3 billion U.S. dollars by 2024 . Television advertising made up the largest share of the Indonesian advertising market, followed by internet advertising. 


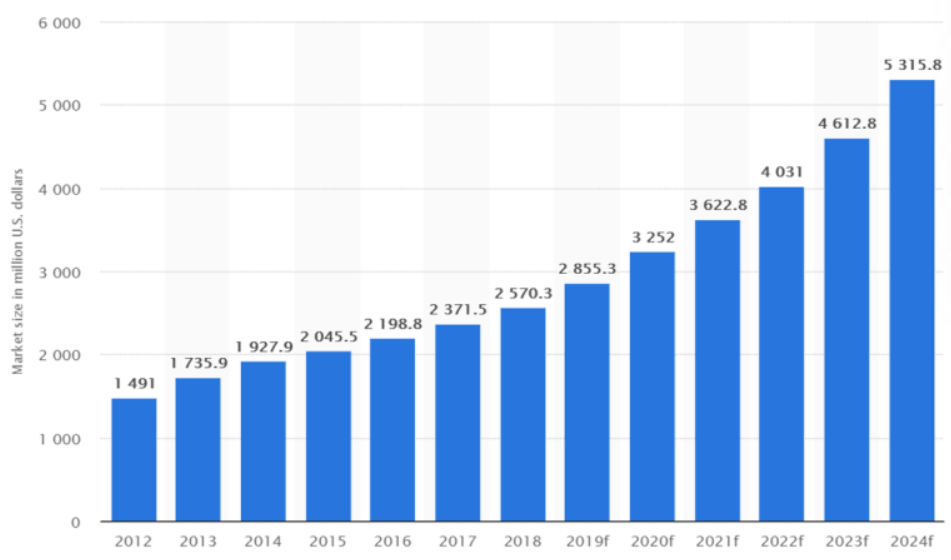

Figure 2 Total advertising market size in Indonesia from 2012 to 2018, with forecasts for 2019 to 2024 (in a million U.S. dollars)

Source: (Hirschmann, 2020)

This research would analyze the contribution of marketing expenditure to the firm performance of telecommunication companies in Indonesia. The statement is justified from the previous research and the data (Hirschmann, 2020), described in figure 2 . In the other data, it was mentioned that Indonesia is among the fastest developing telecommunications market globally, driven by growth in both mobile and fixed broadband subscriptions. Investment in the telecoms sector has grown at a fast pace and maintained momentum is expected in the 2019-2023 period (ResearchAndMarkets.com, 2019).

In this study, firm performances were proxied as the profit margin on sales (PM on Sales), return on assets (ROA), return on investment (ROI), and return on equity (ROE). This study also aimed to give an idea that marketing activities, including marketing expenditure, gives a positive contribution to corporate profits.

\section{Literature Review and Hypotheses Development}

The marketing strategy adopted by the company is closely related to how much it will cost them. It will be an essential assessment for each manager to determine how much the cost will be set to contribute to the company positively.

There are two approaches to the process of determining and preparing marketing costs (Tjiptono, Chandra, \& Adriana, 2008), namely:

\section{Direct Approach}

In this approach, the company, in this case, the marketing manager, will develop a specific estimate of how much sales will result from a specified price or marketing cost. The steps in this direct approach are: 
a. Establishing an industrial sales projection

b. Estimating market share resulting from marketing costs to be incurred

c. Calculating the expected company sales (market share $x$ projected industry sales)

d. Calculating the contribution of variables (company sales $x$ PVCM)

e. Calculating the total contribution (variable contribution margin - direct costs and fixed costs that can be traced)

f. Determining whether sales, market share and total contribution levels, can be accepted based on product goals

\section{Indirect Approach}

In this approach, projected sales productivity at a specific price and cost is not required. The manager estimates whether a given level of sales (benchmark level of sales) can be achieved. The steps in this approach are as follows:

a. Setting the level of total contribution to be achieved

b. Calculating the required level of sales to achieve a targeted contribution to a certain price level and marketing cost

c. Calculating the required market share

d. The projected productivity and marketing costs will determine whether the required sales and market share can be achieved.

e. Determining whether the required market and sales share are acceptable based on product targets

\section{Marketing Expenditure}

According to Cambridge Dictionaries Online, marketing costs are the amount of money allocated by the company for marketing activities. Marketing expenditure is an essential consideration for all businesses because marketing is a key business function that creates customers for the business. It is crucial for business owners to understand the importance of marketing costs, management, and tax treatment. Typically, some general marketing expenditures include marketing salaries, marketing research, promotions, public relations, and advertising costs (Kokemuller, 2013).

Marketing expenditure is a budget allocation, consisting of employee salaries and related costs, media advertising (including printing costs, online, radio, and television), public relations activities, special promotions, trade shows, and production of related items with products, including guarantees and videos (Hunger \& Wheelen, 2012). Meanwhile, according to (Supriyono, 1993), marketing expenditure is all costs occur in the context of marketing a product or merchandise, where costs are incurred from the moment the product or merchandise is ready for sale until receipt of the sale proceeds into cash. Meanwhile, the relationship between advertising expenditures and sales has been discussed; however, whether product market competition affected their relationship has been little examined. This question was addressed by analyzing the financial performance data of 6,018 companies for 14 years (1997-2011). The current data analysis supports two hypotheses: (1) increasing advertising expenditures increase 
sales in the subsequent year, and (2) this effect is more substantial when the product market competition is high than when it is low (Kim \& Joo, 2013).

In an effort to assess marketing costs used for promotional purposes of new product development, each company needs to design a business model capable of tracking the impact of marketing costs on consumer understanding, beliefs, feelings, attitudes, and behavior. A model that can be used is the chain of marketing productivity model (Rust, Ambler, Carpenter, Kumar, \& Srivastava 2004). The model connects the specific actions the company undertakes (marketing actions) with the firm condition (firm) as a whole. The marketing strategy (which includes product strategy, promotion, and other elements) leads to tactical marketing activities (advertising, service, branding, retention programs, and others) to gain marketing impact, smainly corporate profits. An illustration of how the marketing productivity chain runs and its interrelated is presented in Figure 3.

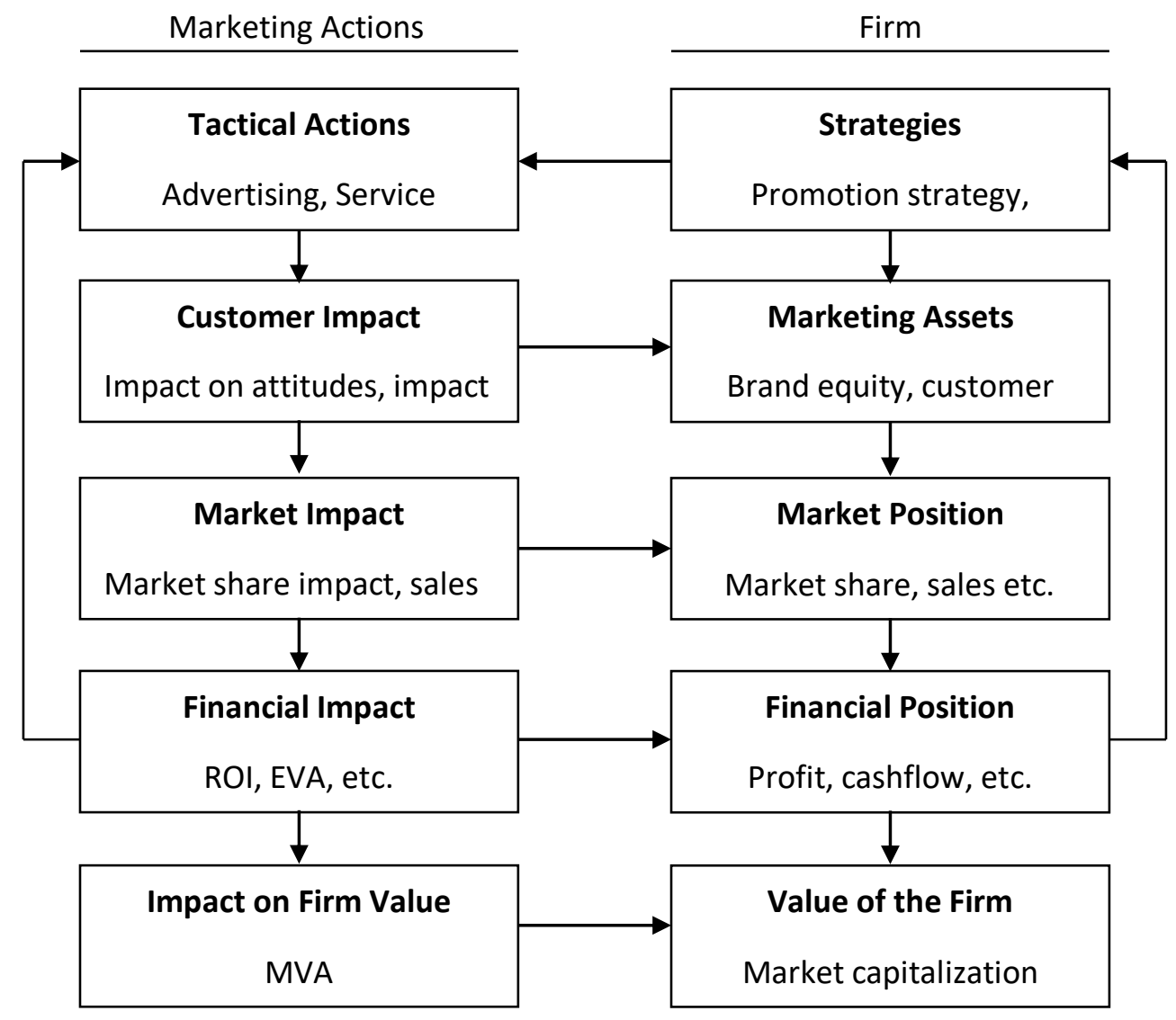

Figure 3. Chain of Marketing Productivity (Rust et al., 2004).

\section{Marketing Expenditure Analysis}

On an ongoing basis, firms must assess appropriate marketing cost levels based on their return on investment and industry standards. Marketing spending should be evaluated and measured across its components, including the general cost to sales ratio, to 
determine its effectiveness. For example, a business owner can calculate a ratio, such as the ratio of advertising to sales, the ratio of promotion to sales, and the ratio of selling costs to sales. By maintaining these ratios and variations and comparing them with industry benchmarks, business owners confirm that they are spending their marketing expenditure effectively and efficiently.

The following table 1 is the marketing expenditure spent by each company in the period 2011-2019.

Table 1 Marketing Expenditure in Periods 2011-2019

\begin{tabular}{ccccc}
\hline Year & PT. Indosar,Tbk & $\begin{array}{c}\text { Marketing Expenditure (in a million rupiahs) } \\
\text { PT. Telkom,Tbk } \\
\text { (induding PT. } \\
\text { Telkomsel) }\end{array}$ & PT. XL Axiata,Tbk & $\begin{array}{c}\text { PT. Smartfren } \\
\text { Telecom, Tbk }\end{array}$ \\
\hline 2011 & 855.700 & 3.044 .000 & 1.238 .000 & 114.754 \\
2012 & 920.300 & 3.092 .000 & 1.306 .000 & 111.767 \\
2013 & 893.600 & 3.275 .000 & 1.355 .000 & 124.956 \\
2014 & 859.500 & 4.132 .000 & 1.424 .000 & 296.134 \\
2015 & 1.236 .679 & 3.725 .000 & 1.433 .000 & 310.394 \\
2016 & 1.237 .831 & 4.214 .000 & 1.127 .000 & 440.681 \\
2017 & 1.282 .800 & 5.268 .000 & 1.615 .500 & 579.762 \\
2018 & 1.228 .930 & 4.214 .000 & 2.038 .624 & 648.487 \\
2019 & 1.145 .457 & 3.724 .000 & 1.970 .279 & 939.362 \\
\hline
\end{tabular}

Source: Annual report of company (www.idx.co.id)

\section{Firm Performance}

One of the company's purposes is to achieve the optimal level of firm performance and guarantee its sustainability. Improved firm performance shows improved corporate performance and comprehensive strategy execution and integrated adequately into every division line. Profitability is another important measure for assessing performance, where a company uncertainly continues to grow without the benefits available for the company to invest (Fitzsimmons, Steffens, \& Douglas 2005). Firm performance is assessed with several analytical tools, such as comparative analysis of financial statements, trend analysis, common size, analysis of sources and use of working capital, analysis of sources and uses of cash, analysis of financial ratios, analysis of changes in gross profit, and break-even analysis (Jumingan, 2006).

\section{Profit Margin on Sales (PM on Sales)}

PM on Sales is one of the ratios used to measure the profit margin of the sale. To measure this ratio, net profit after tax is compared with net sales. This ratio is also known as a profit margin.

The PM on Sales ratio calculates the company's net profit divided by the number of sales. 
The formula:

$$
\text { Profit Margin on Sales }=\quad \frac{\text { Nett Profit }}{\text { Sales }}
$$

1. Return on Assets (ROA)

ROA ratio is employed to measure return on total assets used in company operations. The formula:

$$
\text { Return on Assets }=\quad \frac{\text { Nett Profit }}{\text { Total Asset }}
$$

2. Return on Investment (ROI)

$\mathrm{ROI}$ is a ratio that shows the results (return) on the number of assets used in the company. ROI is also a measure of management effectiveness in managing its investment. The ROI ratio is utilized to measure the firm's essential ability to generate profits by dividing the amount of Revenue and Equity.

The formula:

$$
\text { Return on Investment }=
$$

Revenue

Equity

\section{Return on Equity (ROE)}

ROE is the ratio of net income to ordinary equity used to measure the return on ordinary shareholder investment. Shareholders can know how much dividend return can be seen by using this ratio.

The formula:

$$
\text { Return on Equity }=\quad \frac{\text { Nett Profit }}{\text { Common Equity }}
$$

The components in the measurement of firm performance above are the justification in this study to analyze the impact of marketing expenditure on firm performance.

\section{Previous Research}

1. The Influence of Marketing Activities, Financial Performance, and Intangible Assets to Company Value (Kombih \& Suhardianto, 2017).

a. Variable: (1) marketing activity (expenses), (2) Return on Assets/ROA, (3) Current Ratio/CR, (4) Debt to Equity Ratio/DER, (5) Tobin's Q.

b. Result of research: marketing activity, profitability, and solvency would increase company value. 
2. The Influence of Marketing Activities on Profitability and Value of Property and Real Estate Companies in BEI (Serenia \& Hatane, 2015).

a. Variable: (1) marketing cost, (2) company size, (3) company age, (4) Return on Assets/ROA, (5) Earning Per Share/EPS, (6) Tobin's Q, (7) market to book ratio.

b. Research result:

1) The age of a company as a component of marketing activities had a positive influence on profitability and corporate value.

2) Marketing costs had a positive and significant influence on profitability and firm value represented by EPS and Market to Book Ratio.

3) The size of the company had a negative relationship to profitability and positive to the value of the company represented by EPS and Tobin's $Q$

3. Measuring Marketing Productivity: Current Knowledge and Future Directions. Marketing expenditures add to shareholder value (Rust et al., 2004).

a. Variables under study: (1) strategy and tactics, (2) brand equity, (3) customer equity, (4) market impact, (5) financial impact, (6) environment, and (7) competition. The emphasis was on aggregate-level models that linked tactics with financial impact.

b. Result of research: marketing expense (marketing expenditure) simultaneously impacted the added value to value obtained by shareholders.

\section{Hypothesis Development}

The following is the firm performance ratios that reflect the final outcome of all financial policies and operational decisions (Brigham, 2010).

1. The impact of Marketing Expenditure on Profit Margin on Sales (PM on Sales)

The result of the observation conducted by Kristiyanti, Romdhoni, and Kristi (2019) showed that there was any influence between marketing activity (represented by marketing expenditure, company size, and company age) and profitability, partially, in PT. Krakatau Steel year of 2010 to 2018. On the contrary, the results of a study showed that marketing expenditure variables had no significant influence on profitability (Rahman \& Sunarti, 2017).

Hypothesis 1. Marketing Expenditure impacts Profit Margin on Sales.

2. The impact of Marketing Expenditure on Return on Assets (ROA)

The research conducted by Maulida (2019) showed that promotion costs and labor costs simultaneously influence the level of profitability. Then, the R-Square value was 0.677358 , indicating that the proportion of influence of Promotion Cost (X1) and Labor Cost (X2) to Return on Asset (ROA) of Bank Syariah Mandiri was $67.73 \%$. Another case 
with the results of research conducted by Widhiastuti and Nugraha (2018) revealed that the cost of promotion did not influence the company's profit and value.

Hypothesis 2. Marketing Expenditure impacts Return on Assets (ROA).

3. The impact of Marketing Expenditure on Return on Investment (ROI)

The higher the Return on Investment in the business segment, the larger the segment of the operating assets (Garrison \& Eric, 2007 ). The study conducted by Banerjee and Siddhanta (2015) found budget allocation decisions by informing them of the return on investment duration.

Hypothesis 3. Marketing Expenditure impacts the Return on Investment (ROI).

4. The impact of Marketing Expenditure on Return on Equity (ROE)

ROE was employed to measure the company's success in generating profits for shareholders; therefore, ROE is considered as the representation of shareholder wealth (Mardiyanto, 2009).

Hypothesis 4. Marketing Expenditure impacts Return on Equity (ROE).

\section{Research Framework}

Based on the hypothesis developed in this study, here is an illustration of the research framework:

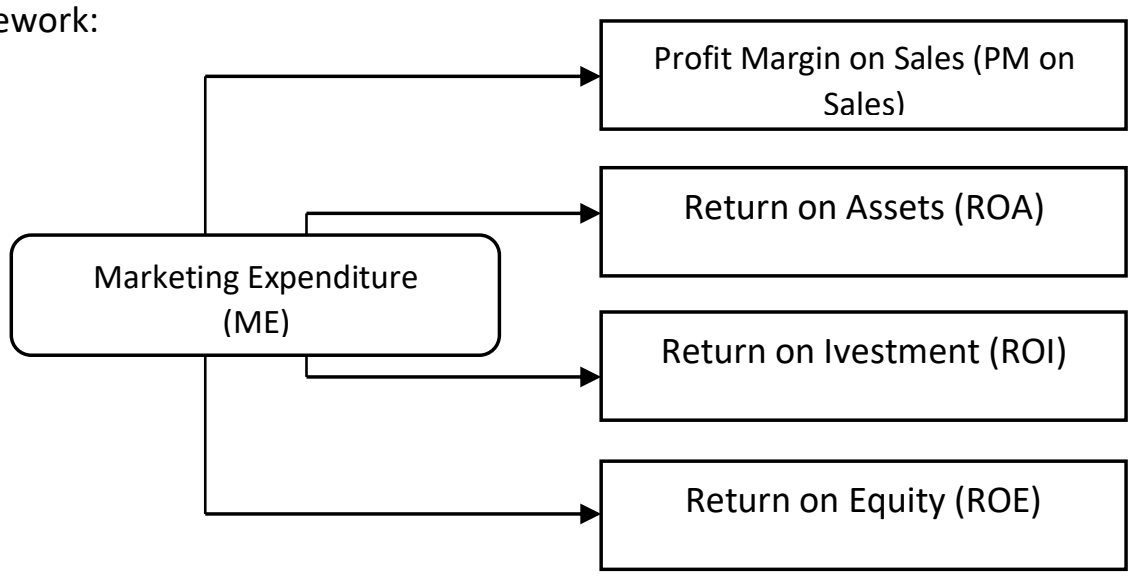

Figure 4. Research Framework 


\section{Research Method}

This research would examine the influence of marketing expenditure on firm performance in a telecommunication company. This type of research was quantitative research.

\section{Sample}

The sample used in this research was a telecommunication company in Indonesia. The Company is PT. Telkom, Tbk (including PT. Telkomsel), PT. Indosat Ooredoo, Tbk, PT. XL Axiata, Tbk, PT. Bakrie Telecom, Tbk, and PT Smartfren Telecom, Tbk. The data were collected from annual reports, which were accessed and downloaded through www.idx.co.id in the period 2011-2019.

\section{Hypothesis Testing Technique}

The analysis technique employed in this research was a linear regression analysis of the variables studied. To test the accuracy of the data, the regression analysis came with the determination of the VIF value.

\section{Result and Discussion}

This research used multiple regression models in the influence of marketing expenditure on firm performance, which was proxied into four components: profit margin on sales (PM on Sales), return on assets (ROA), return on investment (ROI), and return on equity (ROE).

Here is the data recapitulation recorded by telecommunication companies in the period 2011-2018.

Table 2 demonstrates the data recapitulation that aimed to describe the influence of marketing expenditure on the firm performance, which would be tested using the regression model of each variable. 
Haryanto \& Retnaningrum

The Impact of Marketing Expenditure on Firm Performance

Table 2 Recapitulation of PM on Sales, ROA, ROI, and ROE

\begin{tabular}{|c|c|c|c|c|c|c|c|c|c|c|c|c|c|c|c|c|}
\hline \multirow[t]{2}{*}{ Year } & \multicolumn{4}{|c|}{ PT. Indosat, Tbk } & \multicolumn{4}{|c|}{$\begin{array}{c}\text { PT. Telkom, Tbk (including PT } \\
\text { Telkomsel }\end{array}$} & \multicolumn{4}{|c|}{ PT. XL Axiata, Tbk } & \multicolumn{4}{|c|}{ PT. Smartfren Telecom, Tbk } \\
\hline & $\begin{array}{c}\text { Profit } \\
\text { Margin } \\
\text { on Sales }\end{array}$ & ROA & ROI & ROE & $\begin{array}{c}\text { Profit } \\
\text { Margin } \\
\text { on Sales }\end{array}$ & ROA & ROI & ROE & $\begin{array}{c}\text { Profit } \\
\text { Margin } \\
\text { on Sales }\end{array}$ & ROA & ROI & ROE & $\begin{array}{c}\text { Profit } \\
\text { Margin } \\
\text { on Sales }\end{array}$ & ROA & ROI & ROE \\
\hline 2011 & $4,72 \%$ & $5,94 \%$ & $2,87 \%$ & $1,71 \%$ & $30,80 \%$ & $10,60 \%$ & $32,56 \%$ & $23,10 \%$ & $5,00 \%$ & $9,08 \%$ & $20,67 \%$ & 22,30 & $15,00 \%$ & $9,80 \%$ & $86,60 \%$ & $22,30 \%$ \\
\hline 2012 & $1,67 \%$ & $5,78 \%$ & $2,55 \%$ & $1,69 \%$ & $33,30 \%$ & $11,50 \%$ & $35,68 \%$ & $24,90 \%$ & $13,00 \%$ & $7,80 \%$ & $17,99 \%$ & 18,00 & $13,00 \%$ & $7,80 \%$ & $54,60 \%$ & $18,00 \%$ \\
\hline 2013 & $-11,66 \%$ & $2,77 \%$ & $-8,09 \%$ & $1,70 \%$ & $33,60 \%$ & $11,00 \%$ & $34,10 \%$ & $23,70 \%$ & $4,80 \%$ & $2,56 \%$ & $6,75 \%$ & 6,80 & $4,80 \%$ & $2,56 \%$ & $33,88 \%$ & $6,80 \%$ \\
\hline 2014 & $-8,30 \%$ & $-3,80 \%$ & $\begin{array}{c}- \\
15,99 \%\end{array}$ & $1,91 \%$ & $32,60 \%$ & $10,20 \%$ & $32,55 \%$ & $21,40 \%$ & $3,80 \%$ & $-2,17 \%$ & $-9,84 \%$ & 5,70 & $3,80 \%$ & $-2,17 \%$ & $\begin{array}{c}- \\
45,31 \%\end{array}$ & $5,70 \%$ \\
\hline 2015 & $-4,90 \%$ & $-2,40 \%$ & $12,93 \%$ & $2,90 \%$ & $31,70 \%$ & $14,00 \%$ & $31,87 \%$ & $25,00 \%$ & $0,10 \%$ & $-2,66 \%$ & $11,11 \%$ & $-0,20$ & $0,10 \%$ & $-2,66 \%$ & $22,86 \%$ & $-0,20 \%$ \\
\hline 2016 & $3,80 \%$ & $2,20 \%$ & $10,03 \%$ & $8,30 \%$ & $33,70 \%$ & $16,20 \%$ & $32,08 \%$ & $27,60 \%$ & $1,80 \%$ & $-3,60 \%$ & $-9,31 \%$ & 1,80 & $1,80 \%$ & $-3,60 \%$ & $33,64 \%$ & $1,80 \%$ \\
\hline 2017 & $4,35 \%$ & $2,57 \%$ & $19,37 \%$ & $8,10 \%$ & $34,30 \%$ & $16,50 \%$ & $35,27 \%$ & $29,20 \%$ & $1,64 \%$ & $0,67 \%$ & $1,73 \%$ & 1,70 & $-6,47 \%$ & $12,53 \%$ & $\begin{array}{c}- \\
32,69 \%\end{array}$ & $\begin{array}{l}- \\
32,70 \%\end{array}$ \\
\hline 2018 & $-9,01 \%$ & $-3,92 \%$ & $\begin{array}{c}- \\
17,18 \%\end{array}$ & $\begin{array}{c}- \\
21,50 \%\end{array}$ & $29,70 \%$ & $13,10 \%$ & $75,80 \%$ & $23,00 \%$ & $-14,33 \%$ & $-5,72 \%$ & $\begin{array}{c}- \\
17,97 \%\end{array}$ & $-18,00$ & $-6,47 \%$ & $14,09 \%$ & $\begin{array}{c}- \\
28,53 \%\end{array}$ & $\begin{array}{c}- \\
28,50 \%\end{array}$ \\
\hline 2019 & $5,59 \%$ & $2,60 \%$ & $11,89 \%$ & $12,30 \%$ & $31,30 \%$ & $12,50 \%$ & $88,70 \%$ & $23,50 \%$ & $2,83 \%$ & $1,14 \%$ & $3,73 \%$ & 3,80 & $-3,80 \%$ & $-7,91 \%$ & $\begin{array}{c}- \\
17,17 \%\end{array}$ & $\stackrel{-}{17,20 \%}$ \\
\hline
\end{tabular}

Source: Annual financial statement (www.idx.co.id)

Here are the results of the regression test:

Table 3 Result of The Regression Test

\begin{tabular}{|c|c|c|c|c|c|c|}
\hline Model Regression & Constant & $\mathbf{R}$ & $\mathrm{R}^{2}$ & Sig. & Tol. & VIF \\
\hline Marketing Expenditure to Profit Margin on Sales & 1,101 & 0,356 & 0,127 & 0,033 & 1,000 & 1,000 \\
\hline Marketing Expenditure to ROA & 0,363 & 0,123 & 0,015 & 0,474 & 1,000 & 1,000 \\
\hline Marketing Expenditure to ROI & 0,375 & 0,593 & 0,352 & 0,000 & 1,000 & 1,000 \\
\hline Marketing Expenditure to ROE & 4,188 & 0,457 & 0,209 & 0,005 & 1,000 & 1,000 \\
\hline
\end{tabular}

Source: The result of data processing (output SPSS) 
Table 3 explains that each variable tested using linear regression had four different results. First, the marketing expenditure had a positive influence on PM on Sales, significantly. It is in line with the research of Kristiyanti et al. (2019), which showed that there was an impact of marketing activity on profitability. Practically, when the company spends more budget on marketing (promotion, marketing research, and others), the results show that the firm performance increases.

Secondly, marketing expenditure had a significant positive impact on return on investment (ROI). The third results showed that marketing expenditure had a significant impact on the return on equity (ROE). Last, on the contrary, marketing expenditure had no impact on the return on assets (ROA). Moreover, the VIF value was less than 10 (VIF = $1,000)$, which means that the data tested did not occur multicollinearity.

\section{Conclusion}

Based on the results and discussion of research, the conclusion is explained as follows; There was a significant positive influence of marketing expenditure (ME) on the profit margin on sales (pm on sales), with a level of influence of $12.7 \%$ (R2 value). It means that with the marketing expenditure spent, the profit margin on sales of the company would increase by $12.7 \%$. There was no effect of marketing expenditure (ME) on the return on assets (ROA), with a significance score of 0,474 (more than Sig. 0.05). There was a significant positive influence of marketing expenditure (ME) on return on investment (ROI), with an influence level of $35.2 \%$ (R2 value). It indicates that with the marketing expenditure spent, the company's ROI would increase by $5.2 \%$. There was a significant positive effect of marketing expenditure (ME) on return on equity (ROE), with an influence rate of $20.9 \%$ ( $R 2$ value). It denotes that with the marketing expenditure spent, the company's ROE would increase by $20.9 \%$.

The implication of this research is the understanding of the indicator found in the analysis. The main aim of this study was to address the almost total absence of research evidence on what was meant to identify the influence of marketing expenditure on firm performance.

For future research, the other financial aspects should be added as additional variables to provide other factors that affect the firm performance more details, especially in profitability.

\section{References}

Banerjee, N., \& Siddhanta, S. (2015). An Empirical Investigation on the Impact of Marketing Communication Expenditure on Firms' Profitability: Evidence from India. Global Business Review, Volume 16(4), 609-622. https://doi.org/10.1177/0972150915581105 Brigham, H. (2010). Dasar-dasar Manajemen Kenangan. Jakarta: Penerbit Salemba Empat. 
Fitzsimmons, J. R., Steffens, P., \& Douglas, E. J. (2005). Growth and Profitability In Small And Medium-Sized Australian Firms. Proceedings AGSE Entrepreneurship Exchange, Melbourne. https://dx.doi.org/10.2139/ssrn.1263734

Garrison, R. H., \& Eric, W. N. (2007 ). Akuntansi Manajerial. diterjemabkan oleh A. Totok Budisantoso. Jakarta: Salemba Empat.

Hirschmann, R. (2020, January 30). Total advertising market size in Indonesia from 2012 to 2018, with forecasts for 2019 to 2024 (in a million U.S. dollars). Retrieved from www.statista.com: https://www.statista.com/statistics/1092408/indonesia-totaladvertising-market-size/

Hunger, D., \& Wheelen, L. T. (2012). Strategic Management and Business Policy (13th Edition). United States of America: Pearson.

Jumingan. (2006). Analisis Laporan Kenangan. Cetakan Kedua. Jakarta: PT Bumi Aksara.

Kim, Y., \& Joo, J. (2013). The Moderating Effect of Product Market Competition in The Relationship Between Advertising Expenditures and Sales. The Journal of Applied Business Research, 29(4), 1061-1076. https://doi.org/10.19030/jabr.v29i4.8078

Kokemuller, N. What is Marketing expenditure? Retrieved from smallbusiness.chron.com: https://smallbusiness.chron.com/marketing-expense-25648.html

Kombih, M. T., \& Suhardianto, N. (2017). Pengaruh Aktivitas Pemasaran, Kinerja Keuangan, dan Aset Tidak Berwujud Terhadap Nilai Perusahaan. Ekuitas: Jurnal Ekonomi dan Keuangan, 1(3), 281-302. https://doi.org/10.24034/j25485024.y2017.v1.i3.1909

Kristiyanti, L., Romdhoni, A. H., \& Kristi, A. (2019). Analisis Pengaruh Marketing Activity dan Working Capital Terhadap Profitabilitas di PT. Krakatau Steel Tahun 2010-2018. Jurnal Akuntansi dan Pajak, 20(1), 21-28. https:// doi.org/10.29040/jap.v20i1.542

Luo, X., \& Jong., P. J. (2012). Does Advertising Spending Really Work? The Intermediate Role of Analysts in the Impact of Advertising on Firm Value. Journal of the Academy of Marketing Science, 40, 605-624. https://doi.org/10.1007/s11747-010-0240-3

Mardiyanto, H. (2009). Intisari Manajemen Kenangan. edisi Pertama. Jakarta: Grasindo.

Matari, A., \& Mohammed, E. (2014). The Measurements of Firm Performance's Dimensions. Asian Journal of Finance and Accounting, 6(1), 24-49. https://doi.org/10.5296/ajfa.v6i1.4761

Maulida, I.S.R. (2019). Pengaruh Biaya Promosi dan Biaya Tenaga Kerja Terhadap Profitabilitas di PT. Bank Syariah Mandiri. Jumal Ekonomi dan Keuangan Syariah, 3(1), 15-27. https://doi.org/10.29313/amwaluna.v3i1.4180

Moorman, C., \& Rust, R. T. (1999). Fundamental Issues and Directions for Marketing. Journal of Marketing, 63, 180-197. https://doi.org/10.1177/00222429990634s117

Peers, Y., Heerde, H. J., \& Dekimped, M. G. (2017). Marketing Budget Allocation Across Countries: The Role of International Business Cycles. Journal of Marketing Science, 1-18. https://doi.org/10.1287/mksc.2017.1046

Rahman, F., \& Sunarti. (2017). Pengaruh Marketing Expense, Ukuran Perusahaan, dan Umur Perusahaan Terhadap Tingkat Profitabilitas Perusahaan (Studi Empiris Pada Industri Sektor Perbankan Indonesia Yang Listing di BEI Periode 2011-2015). Jurnal Administrasi Bisnis (JAB), 52(1), 146-153. Retrieved from http://administrasibisnis.studentjournal.ub.ac.id/index.php/jab/article/view/2167

ResearchAndMarkets.com. Indonesia's Telecommunications Industry - Revenue Analysis \& Forecasts (2019-2023). Retrieved from www.businesswire.com. : https://www.businesswire.com/news/home/20191127005282/en/IndonesiasTelecommunications-Industry---Revenue-Analysis-Forecasts 
Rust, R. T., Ambler, T., Carpenter, G. S., Kumar, V., \& Srivastava, R. K. (2004). Measuring Marketing Productivity: Current Knowledge and Future Directions. Journal of Marketing, 68(4), 76-89. https://doi.org/10.1509/jmkg.68.4.76.42721

Serenia, S., \& Hatane, S. E. (2015). Pengaruh Kegiatan Marketing terhadap Profitabilitas dan Nilai Perusahaan Properti dan Real Estate di BEI. Business Accounting Review, 3(1), 268279. Retrieved from https://media.neliti.com/media/publications/186579-IDpengaruh-kegiatan-marketing-terhadap-pro.pdf

Sharma, J. K., \& Husain, S. (2015). Marketing expenditure \& Profitability: Evidence from the Telecom Sector in the Kingdom of Saudi Arabia. European Journal of Business and Management, 7, 35, 66-70. Retrieved from http://citeseerx.ist.psu.edu/viewdoc/download?doi=10.1.1.735.254\&rep=rep1\&type $=\mathrm{pdf}$

Supriyono, R. A. (1993). Akuntansi Biaya Perencanaan dan Pengendalian Biaya serta Pembuatan Keputusan. Yogyakarta: BPFE.

Tjiptono, F., Chandra, G., \& Adriana, D. (2008). Pemasaran Strategik. Yogyakarta: Penerbit Andi.

Widhiastuti, S., \& Nugraha, R. R. (2018). Pengaruh Modal Intelektual, Biaya Promosi, Dan Perputaran Persediaan Dalam Mempengaruhi Profit Serta Implikasinya Terhadap Nilai Perusahaan. Jurnal Manajemen Kewirausahaan, 15(2), 183-192. https://doi.org/10.33370/jmk.v15i2.230 